\title{
Urbanisation differently affects decomposition rates of recalcitrant woody material and labile leaf litter
}

\author{
DJ Kotze ${ }^{1} \mathbb{D} \cdot \mathrm{H}_{\text {Setälä }}{ }^{1}$
}

Accepted: 3 May 2021 / Published online: 24 May 2021

(C) The Author(s) 2021

\begin{abstract}
Litter decomposition is a fundamental ecosystem process and service that supplies nutrients to the soil. Although decomposition rate is influenced by litter quality, climatic conditions, the decomposer community and vegetation type in non-urban ecosystems, little is known about the degradation of different organic matter types in urban settings. We investigated the decomposition rates of recalcitrant (wood sticks for 4 years) and labile litter (green tea leaves in pyramid-shaped teabags for 3 years) in urban habitats that differed in level of management and disturbance. We found that recalcitrant woody material decomposed slower in urban habitat types (ca. 60-75\% mass loss after 4 years in remnant spruce forests, park lawns, ruderal habitats) than in natural to seminatural spruce forest soils ( $84 \%$ mass loss) outside the city. Labile tea litter, however, decomposed faster in typical open urban habitats (70\% mass loss after 3 years in park lawns, ruderal habitats) than in forested habitats (60\% mass loss in semi-natural and remnant spruce forests), with a remarkable dichotomy in decomposition rate between open and forested habitats. We suggest that the slower rate of wood decomposition in the city relates to its depauperate saprotrophic fungal community. The faster rate of labile litter decomposition in open habitats is difficult to explain, but is potentially a consequence of environmental factors that support the activity of bacteria over fungi in open habitats. We propose that the reintroduction of decaying woody material into the urban greenspace milieu could increase biodiversity and also improve the ability of urban soils to decompose an array of organic material entering the system. This reintroduction of decaying woody material could either occur by leaving cut logs - due to management - in urban remnant forests, which has been shown to be accepted as natural features by residents in Fennoscandian cities, and by placing logs in urban parks in ways that communicate their intentional use as part of urban landscape design and management.
\end{abstract}

Keywords Litter decomposition $\cdot$ Boreal city $\cdot$ GLUSEEN $\cdot$ Long-term study $\cdot$ Labile litter $\cdot$ Recalcitrant litter

\section{Introduction}

Boreal landscapes are dominated by coniferous forests, which are characterised by soils of low $\mathrm{pH}$, high organic matter content and a fungal-dominated microbial community due to large quantities of dead and decaying wood and other recalcitrant substrates (Esseen et al. 1997; Siitonen 2001; Sterkenburg et al. 2015). Among other land use types,

DJ Kotze

johan.kotze@helsinki.fi

H Setälä

heikki.setala@helsinki.fi

1 Faculty of Biological and Environmental Sciences, Ecosystems and Environment Research Programme, Lahti, University of Helsinki, Niemenkatu 73, FI-15140 Lahti, Finland urbanisation has changed the character of this biome by favouring certain vegetation admixtures and introducing a diversity of habitat types and soils to the urban environment that vary in management regime and disturbance intensity. Consequently, biotic communities are prone to change due to human intervention with concomitant alterations in the functions and ecosystem services they provide (Ziter 2016; Schwarz et al. 2017).

One such function, and important regulating ecosystem service, is litter decomposition, which, among various biotic and abiotic factors, is heavily dependent on the microbial decomposer community in the soil (Schimel and Schaeffer 2012; Sterkenburg et al. 2015). With original habitat in cities shrinking, and anthropogenically-created and disturbed greenspaces becoming more common (Haaland and Konijnendijk van den Bosch 2015), the question arises whether the decomposition of litter of various qualities is impaired in urban greenspaces, and whether the patterns are a consequence of changes in the 
soil microbial community (see Ossola et al. 2017). For example, it is well established that urban soils can be warmer than those outside the city due to the so called urban heat island phenomenon, and that warmer soils stimulate decomposer activity and thus the decomposition rate of organic matter (Byrne 2007; Ossola et al. 2016). Soil temperature can also be affected by the type of vegetation in urban greenspaces (Ossola et al. 2016). This question of whether decomposition is impaired in urban environments is important since the ability of urban greenspace to store atmospheric carbon and nitrogen is directly linked to the plant-soil system (Wardle et al. 2004; Setälä et al. 2016); consequently, as with more natural systems, the type of organic matter - whether labile or recalcitrant - entering the soils in highly managed urban systems should determine whether these soils act as carbon and nitrogen sinks or sources. However, little is known about the influence of, e.g., plant functional types producing divergent litter on this pivotal ecosystem service. Furthermore, this potential effect could be explained by the home-field advantage (HFA) hypothesis, which suggests that litter decomposes faster in its home environment where it derives from than in other environments (Ayres et al. 2009; Milcu and Manning 2011)

The Global Urban Soil Ecology and Education Network (GLUSEEN) was estabished to provide a framework to investigate the effects of different urban vegetation types on soil processes, including litter decomposition (Pouyat et al. 2017). Our current study utilises the same sites from Finland as was used in the GLUSEEN network, except for a few reference sites, i.e., semi-natural spruce forests (see below), that were destroyed in the interim. The GLUSEEN approach adopts many of the same ideas as described in the "habitat structure framework" by Byrne (2007), in which human activities and the consequences on habitat structure manifest themselves in the patterns and processes of urban soils. Results from the GLUSEEN network have shown that ectomychorrhizal fungi decrease in abundance and species richness in soils underneath plant communities that produce labile litter, such as turf/lawn (Epp Schmidt et al. 2017). Furthermore, the relative abundance of wood saprotrophic fungi was shown to be considerably lower in urban park soils compared to soils in the semi-natural habitat outside cities treated as a reference (Epp Schmidt et al. 2017). In related studies in the city of Lahti, but with different research questions and experimental design, Francini et al. (2018) showed that total microbial and bacterial biomasses in soils under urban park trees in the city were about a third lower than in control forests outside the city, and that fungal biomass was substantially higher in conifer tree soils in forests outside the city than in urban parks. Furthermore, Hui et al. (2017a, b) showed that fungal community composition is substantially different in soils under old park trees (ca. > 100 year old trees) versus soils in control forests (over 80 year old trees growing in these very old, practically undisturbed soils) of the same city. These results suggest that both the vegetation and their accompanying microbial decomposer communities in the plant rhizosphere has the potential to affect the decomposition rates of litters of divergent qualities, i.e., leaf litter (here green tea) and woody branches or roots (here wood sticks). Although it is clear that urbanisation affects the functional composition of the soil microbiome (Pouyat et al. 1994; Epp Schmidt et al. 2017; Zhang et al. 2020), decomposition rates of litter of different qualities over a longer period of time in these altered soils are not well studied or understood.

In this study using the GLUSEEN protocol, we investigated decomposition rates of litter of two different qualities (recalcitrant and labile, see Materials and Methods) in urban and natural habitat types that differ in management and disturbance regime. Unlike many studies on litter decomposition, where litter is placed aboveground, our study deals with the decomposition of litter within the soil since the placement of litterbags and wood aboveground in highly disturbed and visited urban habitats is impractical. Besides, a substantial proportion of net primary production in various ecosystems is produced belowground, such as fine and large roots (see Hobbie 2015). The four habitat types investigated, two forested and two open, i.e., with and without tree cover, are the same as used in our previous GLUSEEN studies (see Pouyat et al. 2015, 2017), but this study was only performed in Finland. We used (i) natural to semi-natural conifer forests outside the city, (ii) remnant conifer forests within the city, characterised by a lower density of trees due to management, (iii) urban parks (turf/lawn soils) and (iv) ruderal sites within the city. Differences in decomposition rate across these various urban habitat types will provide knowledge on whether adding primary production to the soil (Wardle et al. 2004) is impaired in disturbed habitat types in human-dominated systems, and if so, highlight the diminishing ecosystem services provided by urban soils and greenspace. We hypothesise that the decomposition rates of recalcitrant (wood sticks, birch) and labile (green tea in triagular green tea bags, Lipton) litters are controlled by, amongst other factors, vegetation type, which determines - via plant-soil dynamics (Wardle et al. 2004; Wall et al. 2015) - the microbial community composition in the soil. Specifically, we hypothesise that abundant fungal communities typical in the soils of conifer-dominated forests will decompose recalcitrant litter (wood sticks) faster than in urban habitat types without trees. Remnant coniferdominated forest patches in urban areas are also expected to decompose recalcitant litter faster, since these urban forests contain dead and decaying wood but at lower volumes (Maene 2005; Korhonen et al. 2020), unless disturbance impairs their soil fungal community (see Malmivaara-Lämsä et al. 2008; Epp Schmidt et al. 2017). Wood decomposition in park and ruderal sites is expected to be slow due to a lack of woody material, which will create a depauperate saproxylic 
microbial community. If labile litter (here green tea litter) is decomposed effectively by both the fungal and bacterial component of the soil microbial community, we hypothesise that there will be no difference in decomposition rates between the habitat types sampled, since such high-quality litter seems not to be affected by edaphic factors, but rather by climate (Fanin et al. 2019). However, leaf litter decomposition rates appear to be affected negatively in forests that experience higher degrees of urbanisation (Melliger et al. 2017; Meyer et al. 2020), but not always significantly so (Enloe et al. 2015). Furthermore, although $\mathrm{N}$ deposition and thus $\mathrm{N}$ availability for soil microbes - particularly for soil bacteria - has been measured to be much higher in urban vs. rural forests (see Carreiro et al. 2000), we expect that potential differences in $\mathrm{N}$ deposition among the four habitat types in our study are not large enough to influence the fungi-bacteria ratio and thus decomposition processes in the soils.

\section{Materials and methods}

The study was performed in Lahti, southern Finland, a city of ca. 120,000 inhabitants situated in the boreal vegetation zone. Annual mean precipitation is $653 \mathrm{~mm}$ and temperature $4.4^{\circ} \mathrm{C}$. Winter lasts between 135 and 145 days, summer between 110 and 120 days and temperatures can vary between -35 and + $35{ }^{\circ} \mathrm{C}$ (Finnish Meteorological Institute: https://en. ilmatieteenlaitos.fi/local-weather/Lahti). The urban heat island effect is expected to be of mimimal significance in Lahti (and thus across our study design), a city beyond $60^{\circ}$ latutude (see Miles and Esau 2017). In Lahti, the underlying bedrock is characterised by mica schist and mica gneiss, and microcline granite. Soil is mostly gravel and sand till. According to the Natural Resources Conservation Service (USDA), the soil order is classified as Spodosol.

Our study design followed the GLUSEEN protocol (Pouyat et al. 2017) with the selection of a matrix of urban land-use categories based on anthropogenic disturbance and management regimes, and a reference (or control) habitat type of minimal disturbance. In total, four categories were investigated, two forested (Reference, Remnant), and two open (Turf/Lawn, Ruderal) (Fig. 1 a-d, for more details on the four habitat types, see Supplementary Material, Appendix S1). Reference habitat sites were located outside the city limits with no or minimal anthropogenic disturbance and management for the past 80 years. Remnant sites were within the city limits and were structurally similar to Reference but with low disturbance and management. Some human disturbance by trampling and emissions of traffic-derived contaminants occur, and light management, including understorey vegetation clearing and the cutting of old and moribound trees take place. Both Reference and Remnant categories were Norway spruce (Picea abies) dominated forest patches with ground cover in the former consisting primarily of blueberry (Vaccinium myrtillus) and in the latter of forest grasses and succulent herbs such as Anemone spp. Canopy trees were at least 60 years old. Turf/Lawn habitat represented high disturbance and moderate management. These unfertilized lawns were distant from trees in urban parks and are primarily for aesthetic and recreational purposes (plots were placed at least at a greater distance than the height of nearby trees). Lawns consisted mostly of Poa and Festuca species and scattered herbs, including Trifolium pratence, Plantago major and Taraxecum spp. Ruderal habitats were highly disturbed or fill areas (building waste dumping) and low management, with sporadically growing vegetation of early successional plants (grasses and herbs). Each of the four land-use categories (Reference, Remnant, Turf/Lawn, Ruderal) was replicated five times with a minimum distance of $150 \mathrm{~m}$ and a maximum distance of ca. $20 \mathrm{~km}$ between any of the sites. Coordinates and soil properties of the 20 sites are presented in the Supplementary Material, Table S1.

Between 2 and 8 May 2015 we buried 25 birch wood 'Lolly sticks' representing recalcitrant litter $(\mathrm{L}=115 \mathrm{~mm}$, $\mathrm{W}=10 \mathrm{~mm} ; \mathrm{C} / \mathrm{N}$ ratio $=116.44$ (after soaking, see below), $n=2$ ) and 20 commercially available nylon mesh, pyramidshaped Lipton green teabags (including Jasmine petals) representing labile litter (mesh-size 280-300 $\mu \mathrm{m} ; \mathrm{C} / \mathrm{N}$ ratio $=$ 9.15 (after soaking), $\mathrm{n}=2$ ) (see Keuskamp et al. 2013) per site using the following protocol (Fig. 1e). Teabags were soaked repeatedly (3-4 times, $20 \mathrm{~min}$ per time) in hot tapwater in the laboratory until most of the colour in the tapwater had disappeared. Green teabags lose up to $40 \%$ of their mass (Pouyat et al. 2017) - the water soluble fraction - during soaking. The teabags were soaked because we were interested in the biological process of decomposition, and not the physical action of leaching, which for these green teabags represent a high percentage of their initial mass. Wood sticks and teabags were air dried, weighed and marked (mean wood stick mass = $1201 \mathrm{mg}, \mathrm{SE}=5.46, n=500$; mean teabag mass $=1161 \mathrm{mg}$, $\mathrm{SE}=1.54, n=400$ ). To account for loss of tea litter fragments during all stages of handling (including sampling, transport and processing), "travel" litterbags were constructed $(n=5)$ (see Dale et al. 2015). Travel litterbags were transported to the most distant study site but immediately returned to the laboratory to calculate 'travel mass loss'. Initial mass of our teabags was corrected for mean travel loss $(<0.6 \%)$.

To prevent the loss of study material, we buried one wood stick and one teabag next to each other in the soil at a depth of 1-3 cm together with a metal nail so that the sample could be located during subsequent field extractions using a metal detector. The pair of stick and teabag placements were repeated to create a $5 \times 5$ matrix setup with each pair $25 \mathrm{~cm}$ apart (Fig. 1e). The final column in the setup consisted only of wood sticks as we assumed wood would decompose slower than tea litter. The field setup was completed in May 2015 and visited after six months (31 October to 5 November 2015), 
Fig. 1 Field sites and study design. a-d: examples of the four land-use categories investigated, e: field setup showing the five birch wood lolly stick and pyramid shaped green teabag pairs per visit $(6 \mathrm{mo}=$ six months after burial, 1 yr, 2 yr, 3 yr, 4 yr = one to four years after burial). Pairs were buried $25 \mathrm{~cm}$ apart, f: a lolly stick and teabag being extracted, $\mathrm{g}$ : stick and teabag drying in the laboratory. Note that the extraction sequence within a plot raises the potential for bias (e: Setup). For instance, an unknown underlying environmental gradient could have been present along one of the extraction periods (say, visit ' $1 \mathrm{yr}$ '). However, the chance of this being the case across all five replicate plots, and for the same extraction is low
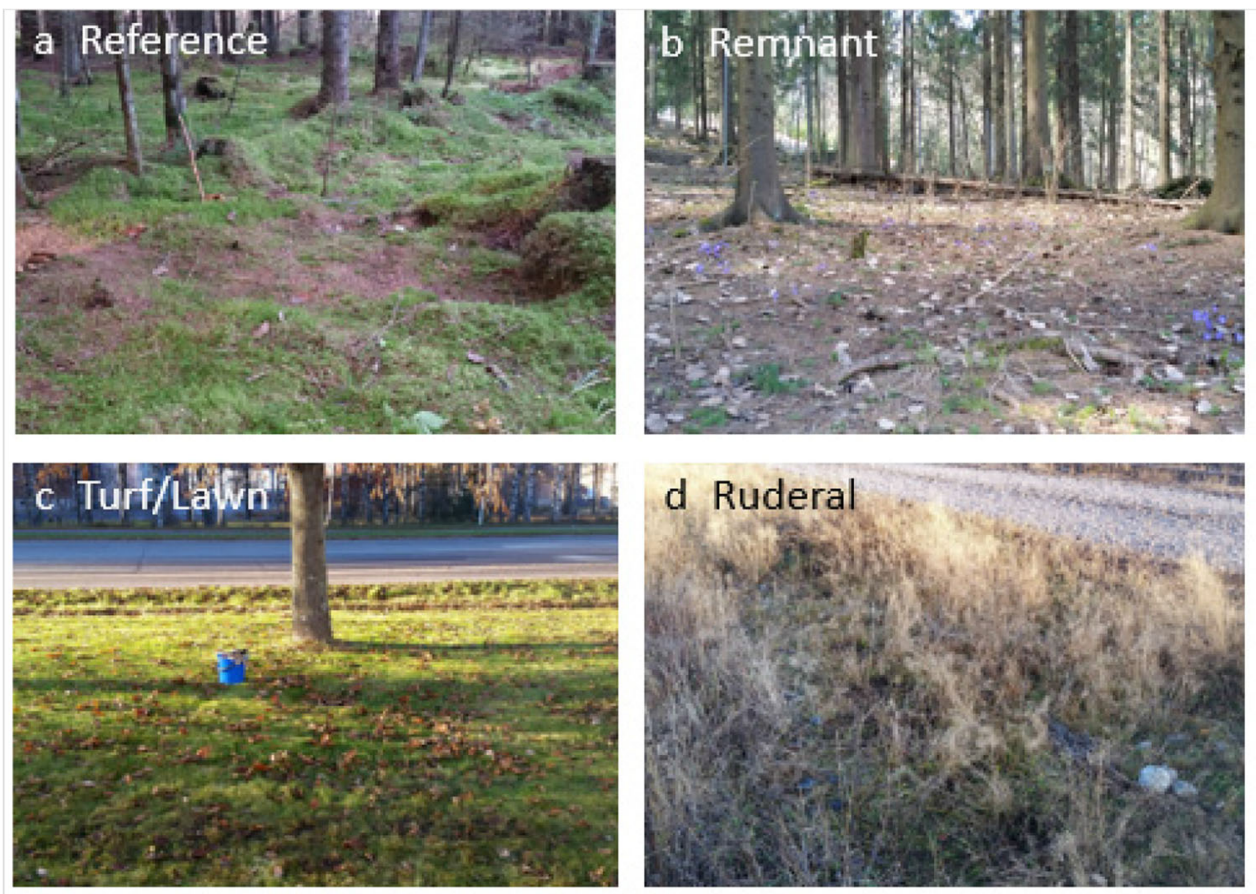

e Setup
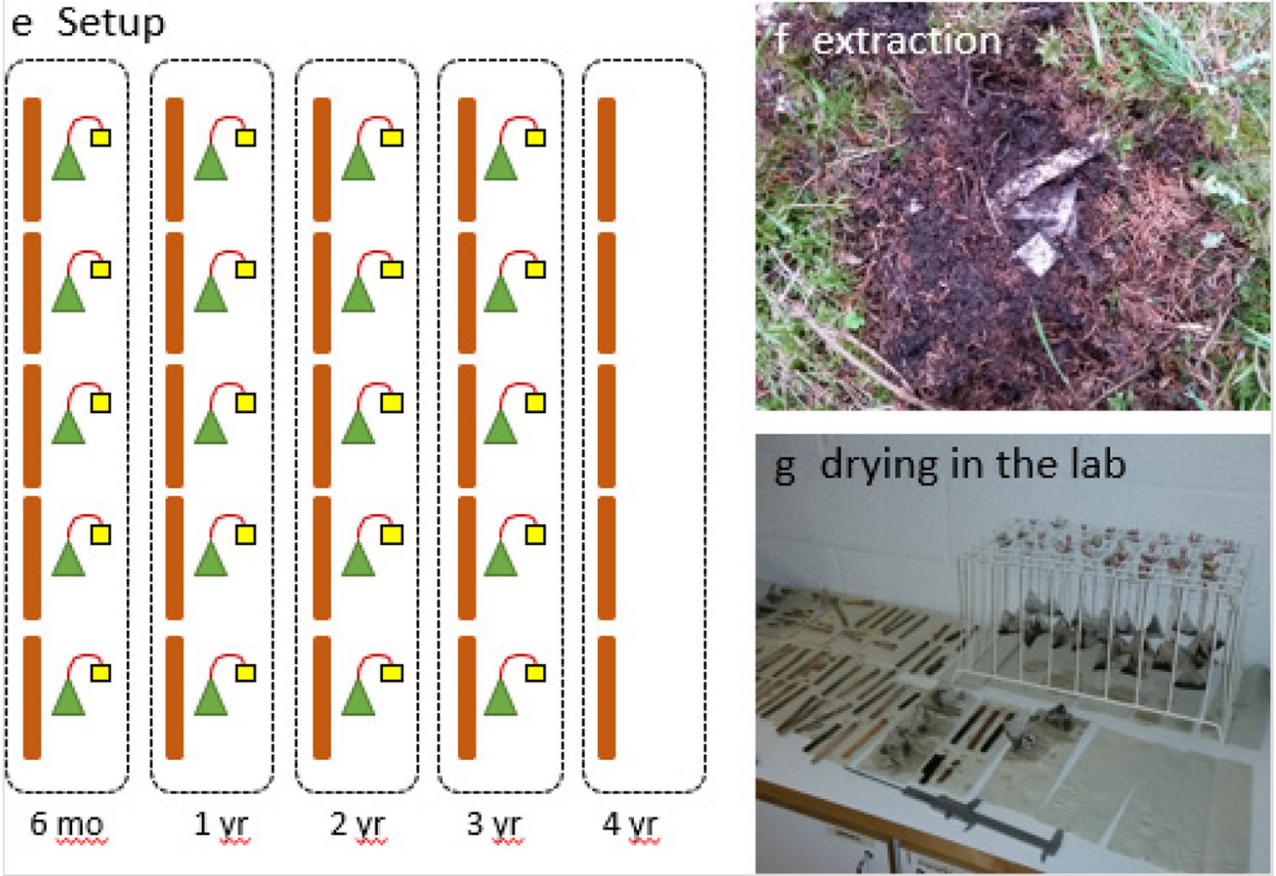

one year (28-29 April 2016), two years (5-10 May 2017), three years (5-7 May 2018), and four years (25-30 April 2019). During each sampling, we removed five wood stick and teabag pairs, except during the last visit when we only removed the remaining five wood sticks per plot.

In the laboratory, the extracted sticks and teabags were gently rinsed and soaked to remove soil, and roots were removed using forceps (Fig. 1f, g), dried in an oven $\left(70{ }^{\circ} \mathrm{C}\right.$, $24 \mathrm{~h}$ ) and weighed. In case only part of a well-decomposed wood stick was retrieved, we measured its length and mass and estimated its total mass using the following formula: (calculated mass / calculated length) $\mathrm{x}$ initial length.

For the measurement of explanatory environmental variables, in May of 2019, we collected three soil subsamples (each ca. $1 \mathrm{dl}$. in volume) from the upper 1-7 cm depth, using a metal soil corer $($ diameter $=2.54 \mathrm{~cm}$ ) at each of the 20 plots. The three subsamples were mixed to create a composite soil sample per site. In the laboratory, soils were sieved through a $2 \mathrm{~mm}$ sieve and $15 \mathrm{~g}$ fresh mass was used for dry matter analysis (after drying for $48 \mathrm{~h}$ at $105^{\circ} \mathrm{C}$ ), percentage organic matter (loss on 
Wood sticks

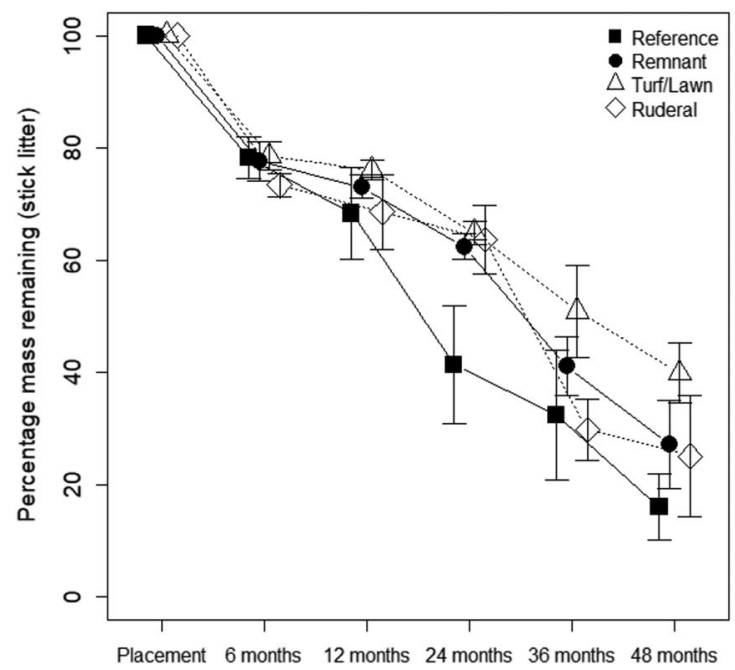

Fig. 2 Percentage mass remaining of wood sticks (left panel) and teabag litter (right panel) after 4 and 3 years in the soil. Posthoc tests were performed on data from the last visit (4 years for wood sticks, 3 years for teabag litter). For wood sticks, a TukeyHSD posthoc test in $\mathrm{R}$ revealed a $p$ value of 0.159 in the comparison between Reference and Turf/Lawn

ignition, $5 \mathrm{~h}$ at $550{ }^{\circ} \mathrm{C}$ in a muffle oven), total carbon and nitrogen (combustion at $1350{ }^{\circ} \mathrm{C}$ using a LECO CNS-2000 Elemental Analyzer; 0.07\% C and 0.09\% N detection limits), the $\mathrm{C} / \mathrm{N}$ ratio and soil $\mathrm{pH}(1: 5 \mathrm{v} / \mathrm{v}$, fresh soil/distilled water).

Using the R statistical software (R Core Team 2018), we performed a one-way ANOVA on the percentage mass remaining after 4 years (wood sticks) and 3 years (teabag litter), with habitat type as a four-level factor (Reference, Remnant, Turf/Lawn, Ruderal). Since the two litter types used are assumed to contain different fractions of labile and recalcitrant pools, we additionally used the asymptotic decomposition model (see Weider and Lang 1982; Riggs et al. 2015; Grossman et al. 2020) to calculate the slow fraction, or pool (A), which is assumed to decompose at a rate of zero and the fast pool, which decomposes at a rate of $k_{a}$,

$X=A+(1-A) e^{-k_{a} t}$,

where $X$ is the proportion of mass remaining in the wood sticks or tea litter at $t$ years after stick and tea litter burial. The

Table 1 Analysis of Variance results, showing the effects of different habitat types on the percentage mass remaining of wood stick (left panel) and tea litter (right panel) at the end of the experiment in and around the city of Lahti, Finland. The Reference habitat type (semi-natural spruce
Tea litter

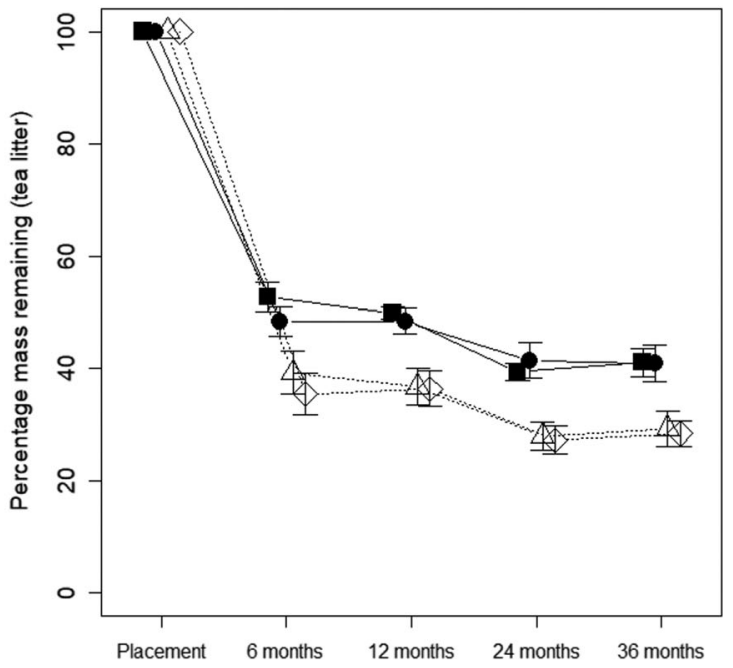

land-use categories, and $p>0.572$ for all other comparisons. For teabag litter, the TukeyHSD test showed no signficant differences between Reference and Remnant, and between Turf/Lawn and Ruderal categories, but clearly between the forested (Reference, Remnant) and open (Turf/Lawn, Ruderal) categories ( $p<0.04$ in all cases)

mle 2 function in the bbmle library in $\mathrm{R}$ was used to calculate $k_{a}$ and $A$.

We rejected the null hypothesis of no difference if a $p$ value was $<0.05$. Histograms and the Shapiro-Wilk test revealed that neither the wood stick nor teabag litter data were significantly different from normal.

\section{Results}

Wood mass loss appeared linear with time irrespective of habitat type. Initially, mass loss was lower for wood sticks, but became similar to teabag litter mass loss after 3 years (Fig. 2). Wood decomposition was consistently higher in reference forests, while remnant and ruderal habitat categories displayed slower rates. Wood decomposition in turf/lawn was consistently the slowest, with $60.1 \%(\mathrm{SE}=5.3)$ of the mass lost after 48 months, compared to ca. $84.0 \%(\mathrm{SE}=5.9)$ of the mass lost in reference forests (Table 1 and Fig. 2), a $28 \%$ difference in

\begin{tabular}{llllllrr}
\hline Wood sticks & Estimate & SE & $p$ & Tea litter & Estimate & SE & p \\
\hline Intercept & 16.033 & 7.552 & 0.051 & Intercept & 41.099 & 2.831 \\
Remnant & 11.105 & 10.680 & 0.315 & Remnant & -0.140 & 4.004 \\
Turf/Lawn & 23.851 & 10.680 & 0.041 & Turf/Lawn & -11.917 & 4.004 \\
Ruderal & 9.025 & 11.328 & 0.438 & Ruderal & -12.723 & 4.004 \\
\hline
\end{tabular}


mass loss. Teabag litter lost a considerable $\%$ of mass after 6 months, with two distinct patterns: typical urban habitats (turf/lawn and ruderal habitat) lost $60.8 \%(\mathrm{SE}=3.8)$ and $64.6 \%$ ( $\mathrm{SE}=3.8$ ) of their mass, respectively, while percentages in reference and remnant forests were $47.3 \%(\mathrm{SE}=2.3)$ and $51.7 \%$ ( $\mathrm{SE}=2.6)$, respectively. Mass loss decreased after the first 6 months, but the dicohtomous pattern persisted throughout the 36 month period, resulting in a significant difference in mass loss between the open (turf/lawn/ruderal: 70-72\%) and forested (reference/remnant: 59\%) categories at the end of the field experiment (Table 1 and Fig. 2), a difference of $18 \%$ in mass loss.

The $k_{a}$ and $A$ values of the decomposing material per habitat and litter type are presented in the Supplementary Material, Table S2. The proportion of initial mass remaining at asymptote $(A)$, i.e., the remaining recalcitrant fraction, was similar between the wood sticks and tea litter, but did show significant differences between habitat types within litter type: for wood sticks, $A$ was signficantly higher in Tufl/Lawn than in either Reference or Ruderal habitat types, while for tea litter the forested habitats had signifcantly higher values than the open habitat types. The rate of decompostion of the labile fraction of the litter $\left(k_{a}\right)$ was ca. 5 times higher for the tea litter than the wood stick litter. Additionally, no significant differences were found in $k_{a}$ between habitat types for both litter types (Supplementary Material, Fig. S1, Table S3).

Soil properties differed among the four habitat categories (Supplementary Material, Table S1) with \% OM, \% C and \% $\mathrm{N}$ decreasing from reference to remnant to turf/lawn to ruderal. Soil $\mathrm{pH}$ was low in both reference and remnant forests (means \pm standard errors: $5.16 \pm 0.15$ and $5.13 \pm 0.10$, respectively), and higher in turf/lawn and ruderal habitats (6.31 \pm 0.17 and $6.60 \pm 0.12$, respectively). The $\mathrm{C} / \mathrm{N}$ ratio of the soil was highest in the reference habitat $(20.14 \pm 1.94)$, and varied between 14.9 and 17.6 in the other three habitat categories.

\section{Discussion}

This study stands out in urban decomposition research, which typically do not investigate decomposition for an extended period of time (see Djukic et al. 2018; Fanin et al. 2019). We showed that urbanisation can have a negative effect on a crucial function and ecosystem service in open lawn and ruderal habitat as well as remnant forests (see Pouyat et al. 2017), i.e., that of wood decomposition. As hypothesised, this long-term decomposition study revealed that recalcitrant woody litter decomposed consistently faster in natural forests outside the city compared to various human-disturbed habitat types within the city, including remnant urban forests, suggesting impairment of this ecosystem service in the city. Four years of wood decomposition resulted in an almost linear loss of mass up to $84 \%$ in semi-natural forests, and between 60 and $75 \%$ in habitat types in the city that have altered saprotropic microbial communities (see Epp Schmidt et al. 2017; Hui et al. 2017a, b). Although decomposition rate is typically slow in forested habitats in the boreal zone, the $84 \%$ loss of the woody sticks within our 4-year study is surprisingly high. The labile litter (teabag litter) mass loss pattern is perplexing, with a rapid loss of mass of leaf litter after six months (between 50 and $60 \%$ ) and little decomposition taking place thereafter. It should be noted that the tea litter had already lost most of its soluble constituents when thoroughly rinsing the bags at the beginning of the study. Interestingly, in the open habitats dominated by herbs and grasses, labile litter mass loss (70\% after 3 years) was significantly greater compared to the two forested habitats (ca. $60 \%$ ), which is difficult to explain but may be due to the prevalence of the soil bacterial community and warmer soils in open habitats (see below). The decomposition patterns observed here, i.e., differences in mass loss between the habitat types investigated, appear to be the result of the recalictrant fraction (the slow $\operatorname{pool} A$ ) of the wood stick and tea litters, and less the result of the decomposition of the labile fraction $\left(k_{a}\right)$ of these litters (see also Riggs et al. 2015).

Lawns in parks are practically devoid of woody material, with this habitat type consistently showing the slowest rate of wood decomposition. This is likely because lawn soils supported a depauperate saprotrophic fungal community (Fig. 3, Epp Schmidt et al. 2017), and because wood decomposition can be inhibited by arbuscular mycorrhizal fungi (Leifheit et al. 2015), common symbionts in grassy habitats (Finlay 2004; GarcíaParisi and Omacini 2017). However, we are not aware of any research performed on the effects of AM fungi on woody material decompostion in lawns, and these explanations remain speculative. The other three habitat types all had some woody material in the soil (results not shown). Not surprisingly, wood decomposition rates were highest in forests outside the city, which also host high relative abundances of Basidiomycota fungi (Hui et al. 2017a) that degrade litter rich in lignin and cellulose. Interestingly, decomposition rates were similar between urban remnant forests and ruderal sites, with the former consising of considerably more dead and decaying wood than the latter. Different processes may result in similar, but intermediate, decomposition rates between these two habitat types. For instance, remnant forests experience anthropogenic disturbances, including trampling and the removal of some dead and decaying wood (Hamberg et al. 2008; Hauru et al. 2014) that affect the soil microbial community (Malmivaara-Lämsä et al. 2008). This can result in lower decomposition rates (compared to rates in natural forests), yet sufficient woody material persists in these urban forests to support moderate decomposition rates. In ruderal environments, woody material, of both native (young trees, woody shrubs) and foreign origin (boards and other buiding debris), is less abundant, and sites are more exposed to the sun than remnant forests, conditions that potentially induce the moderate decomposition rates observed here (see Pouyat and Carreiro 2003). It remains uncertain why the decomposition rate of woody 


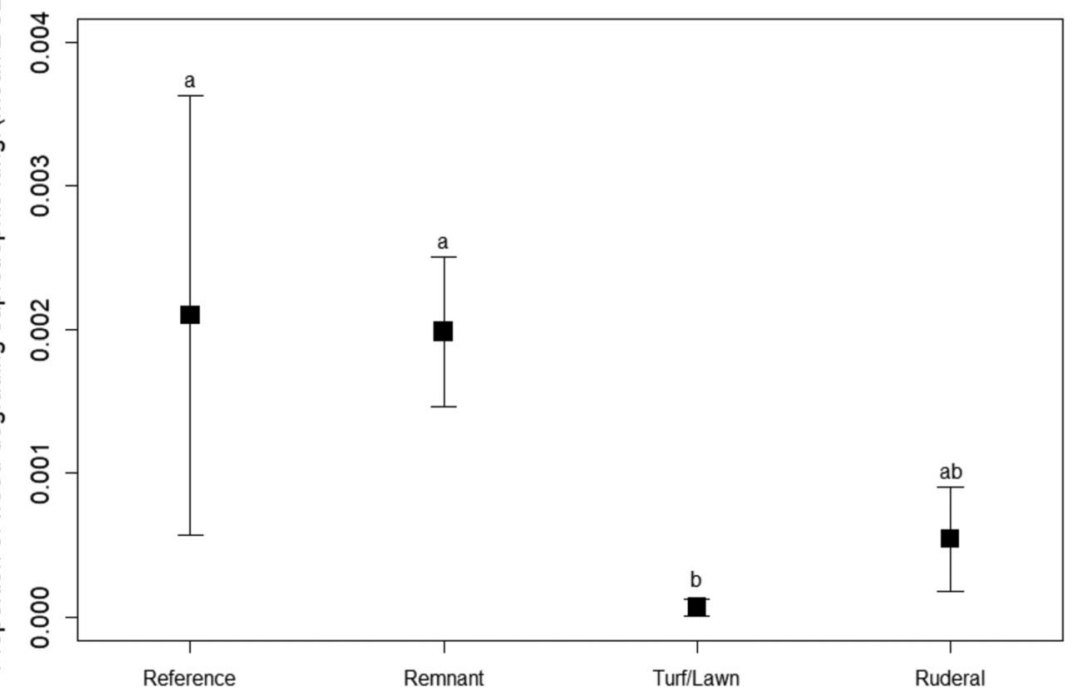

Fig. 3 Proportion (ITS gene abundance) of wood degrading saprothropic fungi in the urban (Remnant, Turf/Lawn and Ruderal) and natural/seminatural (Reference) soils sampled in the current study in and around the city of Lahti, Finland. Data were extracted from Epp Schmidt et al. (2017). Data were transformed (lambda $=0.325$, using the transformTukey function in the rcompanion library in R) to satisfy

material was often higher in ruderal sites compared to park lawns. It may relate to the higher abundance of decomposer fungi at ruderal sites (Fig. 3) and the moderate amount of dead woody material here. Overall, decomposition rates of woody material seems to be impaired in urban areas devoid of woody material, such as park lawns, and to a lesser extent by urbanisation per se (i.e., remnant forests and ruderal land that both host some dead woody material), likely a consequence of an impoverised saprotrophic wood decaying fungal community in these urban areas (Fig. 3, Epp Schmidt et al. 2017).

Contrary to expectation, labile litter decomposition rates were clearly different between the open (ruderal and park lawn) and forested (semi-natural and remnant forest) habitats, with significantly higher rates in the former. Furthermore, our results do not support other studies (Enloe et al. 2015; Melliger et al. 2017; Meyer et al. 2020) that have shown that litter decomposition is affected negatively in forest stands that display higher degrees of urbanisation compared to forests of lower levels of urbanisation (in our case semi-natural vs. remnant forests). Additionally, our findings contradict Ossola et al. (2016) who showed that litter decomposition rates are higher in complex environments (in terms of vegetation structure) compared to low-complexity environments, irrespective of whether the habitat was an urban remnant forest or a park in Melbourne, Australia. Their findings are, however, likely influenced by macrofauna detritivores, which had access to the litter. In our study, the teabags used did not allow access for these fauna. It is clear that the labile part of green tea litter decomposes and/or leaches out within six months or less (see also Keuskamp et al. 2013; Pouyat et al. 2017). However, the tea litter used in our study also consists of components that appear more resistant to decomposition, thus a two-part process

assumptions of normality. A linear model and subsequent TukeyHSD post-hoc test revealed significant differences (indicated by different letters in the plot) between Reference forest and Turf/Lawn ( $p=0.041)$, between Remnant forest and Turf/Lawn $(p=0.012)$, and near significance between Remnant forest and Ruderal $(p=0.1)$

of rapid mass loss, followed by very slow mass loss (see Augusto et al. 2015; Fan et al. 2017). We soaked the teabags thoroughly before field placement - unlike other studies using this method to remove the water-soluble fraction of the litter. Yet between 50 and $60 \%$ of mass was still lost within 6 months, which probably constitutes the non-water-soluble, but labile fraction of green tea litter. Fan et al. (2017), using intact, field-collected tea leaves in a field study, showed that total polyphenol content in tea leaves (which accounts for approximately $33 \%$ of the total mass of tea leaves) decreased rapidly within two months of decomposition so that less than $10 \%$ remained, and that about $20 \%$ of watersoluble carbohydrates remained after 2 months. Hemicellulose in these tea leaves changed little during their 8-month decomposition study (Fan et al. 2017). In our experiment, material (likely constituting hemicellulose and lignin) left in the teabags after 6 months did not decompose readily, which can be due to the inability of larger decomposers, the soil meso- and macrofauna, to enter the bags via the small mesh and fragment the litter (Setälä et al. 1996; Bradford et al. 2002; Meyer et al. 2020). The significantly higher mass loss of tea litter in the open (park lawn and ruderal) compared to the forested (semi-natural and remnant forests) habitats likely resulted from the difference in decomposition of the recalcitrant fraction of the tea litter between open and forested habitats. The asymptotic decomposition model showed that the decomposition rate of the labile fraction of tea litter did not differ between habitat types but that the asymptotic mass of the remaining tea litter was significantly lower in the open compared to the forested habitats. This suggests that the recalcitrant fraction of the tea litter was decomposed faster in open habitats (see the HFA hypothesis below). Additionally, soil microbial activity in open habitats may have been enhanced due to a 
warmer (see Savva et al. 2010) soil compared to the cooler forested habitats, thus resulting in faster decomposition rates of tea litter in these environments. However, as night-time temperatures are likely higher in closed forested habitats (Karlsson 2000), the effect of soil temperature on decomposition rate in our study remains unknown. Finally, grassy habitats support bacterial communities that are adapted to decompose labile material (Wardle et al. 2004; Bardgett and Wardle 2010) and are less sensitive to physical and chemical disturbances, including for example mowing and repeated trampling leading to soil compaction than, e.g. soil fungi (Bailey et al. 2002; Hedlund et al. 2003).

Besides the soil microflora, soil fauna, particularly earthworms, have a strong impact on the decomposition of organic matter (Holdsworth et al. 2012). Even though tea litter in the teabags and wood sticks would not be much affected by direct earthworm feeding, the presence of earthworms in urban habitats (see Pouyat et al. 1997) can have an indirect, negative effect on wood decay via adverse impacts on soil fungal abundances because of their soil mixing behaviour. However, a recent study on earthworms from the majority of sites sampled here showed that earthworm biomass was significantly higher in remnant forests and park lawns, compared to reference forests and ruderal sites (Tóth et al. 2020), and is thus an unlikely explanation of the patterns observed here.

That the properties of the soil decomposer community partly explained the divergent degradation rate of the two litter types in the various habitats is supported, to some extent, by the home field advantage hypothesis (HFA) (Ayres et al. 2009; Milcu and Manning 2011), where litter associated with forests (wood sticks) decomposed quicker in forests, especially the semi-natural forests outside the city, and litter associated with open habitats (tea litter) decomposed quicker in grassy environments. Veen et al. (2015) evaluated the HFA hypothesis from 125 reciprocal litter transplant experiments and found an overall positive effect of litter-site interactions on decomposition rate at 'home', yet showed that HFA effects are context-dependent. Our results add to the litter quality discussion, showing that litters associated with forested habitats, here recalcitrant litter of foreign origin (lolly sticks, $\mathrm{C} / \mathrm{N}$ ratio $=116.44)$, decomposed faster in an environment that is characterised by recalcitrant material, while labile litter (green tea in teabags, $\mathrm{C} / \mathrm{N}$ ratio $=9.15$ ) is decomposed faster in grassy environments that are characterised by labile litter. It is important to remember that the differences observed in litter mass loss between the different habitat types were primarily the result of the recalcitrant fraction (i.e., the slow pool $A$ ) in the litter. Furthermore, our results support the habitat structure framework of Byrne (2007), which emphasizes that the human alteration of physical matter has multivariate impacts on ecosystem processes. In turn, spatial patterns of habitat structure have far reaching consequences for the rate and provision of ecosystem services in urbanised landscapes.
The manicured nature of much urban greenspace has resulted in less detritus in cities, especially that which is perceived as messy, such as dead and decaying wood. This is not only true in parks and gardens, but also in remnant vegetation, such as forests, where felled trees have traditionally been removed as part of forest management (see Hauru et al. 2014). Less detritus in cities in Fennoscandia appears to affect the decomposer community negatively, which impairs the important regulating ecosystem service of decomposition. We showed that the ecological process of decomposition in urban habitats with little decaying wood is impaired, and recommend the reintroduction of this valuable resource to the urban landscape to prevent the gradual impoverishment of species diversity and the functions it provides in urban areas. For instance, leaving more fallen or cut trees to form dead wood in urban remnant forests would elevate these stands to the status of valuable urban forests (see Koronen et al. 2020), which are nowadays accepted as natural features in urban forests in Finland (Hauru et al. 2014). The challenge is to reintroduce woody debris into manicured urban environments, like private gardens and public parks. For public spaces, such as parks, the concept 'cues to care' (Nassauer 1995, Li and Nassauer 2020) can be used as a design tool to emphasise the purpose or intent of the introduced element to the lanscape. For instance, larger logs and snags can be placed in a certain location in public parks to show intent together with information posts to explain the benefits of dead and decaying debris in the ecosystem. These ecosystem services benefits include: i) restoring the process of decomposition that returns primary production to the soil (Wardle et al. 2004), ii) providing habitat for a number of often threatened taxa associated with dead and decaying wood (Siitonen 2001, Kotiranta et al. 2019), and iii) reconnnecting (and educating) people with nature that looks messy and hides function. If successful, such a visual display together with information on the benefits of woody debris could potentially result in the introduction of such elements to private back gardens as part of garden features.

To conclude, this long-term study revealed that the decomposition of recalcitrant woody material is impaired in urban greenspace, when compared to semi-natural forests outside the city, likely a consequence of less woody debris and thus a depauperate saprotrophic microbial community in the soil. Labile litter decomposes consistently faster in open urban habitats than in canopied ones, possibly a result of environmental variables favourable for soil bacterial activity. We propose the conservation and even reintroduction of woody material to urban greenspace to enhance urban soil biodiversity and the capacity of these soils to provide multiple ecosystem services.

Supplementary Information The online version contains supplementary material available at https://doi.org/10.1007/s11252-021-01125-3.

Acknowledgements We thank the city of Lahti, including Markku Saari and Markus Niemelä for encouraging research in their urban greenspaces. 
Richard Pouyat provided usefull comments on an earlier draft of the manuscript. The associate editor and two reviewers provided valuable comments to an earlier version of the manuscript. Lu Changyi is thanked for his help in calculating parameters of the asymptotic decomposition model and in its interpretation.

\section{Availablity of data and material Upon request from the authors.}

Author's contribution DJK and HS conceived of and designed the study and performed field and labwork. DJK analyzed the data and led the writing of the manuscript.

Funding Open access funding provided by University of Helsinki including Helsinki University Central Hospital. The GLUSEEN network is supported by a supplemental grant to NSF-ACI 1244820 .

\section{Declarations}

Ethics approval Not applicable.

\section{Concent to participate Not applicable.}

Consent for publication The authors give concent to publish this work in Urban Ecosystems, if accepted.

Conflicts of interest/competing interests The authors declare that they have no conflict of interest.

Open Access This article is licensed under a Creative Commons Attribution 4.0 International License, which permits use, sharing, adaptation, distribution and reproduction in any medium or format, as long as you give appropriate credit to the original author(s) and the source, provide a link to the Creative Commons licence, and indicate if changes were made. The images or other third party material in this article are included in the article's Creative Commons licence, unless indicated otherwise in a credit line to the material. If material is not included in the article's Creative Commons licence and your intended use is not permitted by statutory regulation or exceeds the permitted use, you will need to obtain permission directly from the copyright holder. To view a copy of this licence, visit http://creativecommons.org/licenses/by/4.0/.

\section{References}

Augusto L, De Schrijver A, Vesterdal L, Smolander A, Prescott C, Ranger J (2015) Influences of evergreen gymnosperm and deciduous angiosperm tree species on the functioning of temperate and boreal forests. Biol Rev 90:444-466

Ayres E, Steltzer H, Simmons BL, Simpson RT, Steinweg JM, Wallenstein MD, Mellor N, Parton WJ, Moore JC, Wall DH (2009) Home-field advantage accelerates leaf litter decomposition in forests. Soil Biol Biochem 41:606-610

Bailey VL, Smith JL, Bolton H Jr (2002) Fungal-to-bacterial ratios in soils investigated for enhanced $\mathrm{C}$ sequestration. Soil Biol Biochem 34:997-1007

Bardgett RD, Wardle DA (2010) Aboveground-belowground linkages: biotic interactions, ecosystem processes and global change. Oxford University press (series in ecology and evolution), Oxford, UK

Bradford MA, Tordoff GM, Eggers T, Jones TH, Newington JE (2002) Microbiota, fauna, and mesh size interactions in litter decomposition. Oikos 99:317-323
Byrne LB (2007) Habitat structure: a fundamental concept and framework for urban soil ecology. Urban Ecosyst 10:225-274

Carreiro MM, Sinsabaugh RL, Repert DA, Parkhurst DF (2000) Microbial enzyme shifts explain litter decay responses to simulated nitrogen deposition. Ecology 81:2359-2365

Dale SE, Turner BL, Bardgett RD (2015) Isolating the effects of precipitation, soil conditions, and litter quality on leaf litter decomposition in lowland tropical forests. Plant Soil 394:225-238

Djukic I, Kepfer-Rojas S, Schmidt IK, Larsen KS, Beier C, Berg B, Verheyen K, TeaComposition (2018) Early stage litter decomposition across biomes. Sci Total Environ 628-629:1369-1394

Enloe HA, Lockaby BG, Zipperer WC, Somers GL (2015) Urbanization effects on leaf litter decomposition, foliar nutrient dynamics and aboveground net primary productivity in the subtropics. Urban Ecosyst 18:1285-1303

Epp Schmidt DJ, Pouyat R, Szlavecz K, Setälä H, Kotze DJ, Yesilonis I, Cilliers S, Hornung E, Dombos M, Yarwood SA (2017) Urbanization erodes ectomycorrhizal fungal diversity and may cause microbial communities to converge. Nature Ecol Evol 1(0123):1-9

Esseen P-A, Ehnström B, Ericson L, Sjöberg K (1997) Boreal forests. Ecol Bull 46:16-47

Fan D, Fan K, Yu C, Lu Y, Wang X (2017) Tea polyphenols dominate the short-term tea (Camellia sinensis) leaf litter decomposition. J Jejiang Univ-Sc B (Biomedicine \& Biotechnology) 18:99-108

Fanin N, Bezaud S, Sarneel JM, Cecchini S, Micolas M, Augusto L (2019) Relative importance of climate, soil and plant functional traits during the early decomposition stage of standardized litter. Ecosystems 23:1004-1018

Finlay RD (2004) Mycorrhizal fungi and their multifunctional roles. Mycologist 18:91-96

Francini G, Hui N, Jumpponen A, Kotze DJ, Romantschuk M, Allen JA, Setälä H (2018) Soil biota in boreal urban greenspace: responses to plant type and age. Soil Biol Biochem 118:145-155

García-Parisi PA, Omacini M (2017) Arbuscular mycorrhizal fungi can shift plant-soil feedback of grass-endophyte symbiosis from negative to positive. Plant Soil 419:13-23

Grossman JJ, Cavender-Bares J, Hobbie SE (2020) Functional diversity of leaf litter mixtures slows decomposition of labile but not recalcitrant carbon over two years. Ecol Monogr 90:e01407

Haaland C, Konijnendijk van den Bosch C (2015) Challenges and strategies for urban green-space planning in cities undergoing densification: a review. Urban For Urban Gree 14:760-771

Hamberg L, Lehvävirta S, Malmivaara-Lämsä M, Rita H, Kotze DJ (2008) The effects of habitat edges on understorey vegetation in urban forests in Helsinki, Finland. Appl Veg Sci 11:81-96

Hauru K, Koskinen S, Kotze DJ, Lehvävirta S (2014) The effects of decaying logs on the aesthetic experience and acceptability of urban forests - implications for forest management. Landscape Urban Plan 123:114-123

Hedlund K, Santa Regina I, Van der Putten WH, Lepš J, Díaz T, Korthals GW, Lavorel S, Brown VK, Gormsen D, Mortimer SR, Rodríguez Barrueco C, Roy J, Smilauer P, Smilauerová M, Van Dijk C (2003) Plant species diversity, plant biomass and responses of the soil community on abandoned land across Europe: idiosyncracy or abovebelowground time lags. Oikos 103:45-58

Hobbie SE (2015) Plant species effects on nutrient cycling: revisiting litter feedbacks. Trends Ecol Evol 30:357-363

Holdsworth AR, Frelich LE, Reich PB (2012) Leaf litter disappearance in earthworm-invaded northern hardwood forests: role of tree species and the chemistry and diversity of litter. Ecosystems 15:913-926

Hui N, Jumpponen A, Francini G, Kotze DJ, Liu X, Romantschuk M, Strömmer R, Setälä H (2017a) Soil microbial communities are shaped by vegetation type and park age in cities under cold climate. Environ Microbiol 19:1281-1295 
Hui N, Liu X, Kotze DJ, Jumpponen A, Francini G, Setälä H (2017b) Ectomycorrhizal fungal communities in urban parks are similar to those in natural forests but shaped by vegetation and park age. Appl Environ Microb 83(23):e01797-e01717

Karlsson IM (2000) Nocturnal air temperature variations between forest and open areas. J Appl Meteorol Clim 39:851-862

Keuskamp JA, Dingemans BJJ, Lehtinen T, Sarneel JM, Hefting MM (2013) Tea bag index: a novel approach to collect uniform decomposition data across ecosystems. Methods Ecol Evol 4:1070-1075

Korhonen A, Siitonen J, Kotze DJ, Immonen A, Hamberg L (2020) Stand characteristics and dead wood in urban forests: potential biodiversity hotspots in managed boreal landscapes. Landscape Urban Plan 201: 103855

Kotiranta H, Junninen K, Halme P, Kytövuori I, von Bonsdorff T, Niskanen T, Liimatainen K (2019) Kääväkkäät [Aphyllophoroid fungi]. Hyvärinen E, Juslén A, Kemppainen E, Uddström A, Liukko U.-M, editors. Suomen lajien uhanalaisuus-punainen kirja 2019 [The 2019 Red List of Finnish Species] Helsinki, Finland: Ministry of the Environment \& Finnish Environment Institute (In Finnish with English summary): p263-312

Leifheit EF, Verbruggen E, Rillig MC (2015) Arbuscular mycorrhizal fungi reduce decomposition of woody plant litter while increasing soil aggregation. Soil Biol Biochem 81:323-328

Li J, Nassauer JI (2020) Cues to care: a systematic analytical review. Landscape Urban Plan 201:103821

Maene S (2005) Dead wood in urban forests in Helsinki, Finland. MSc Dissertation. Department of Biological and Environmental Sciences, Faculty of Biosciences, University of Helsinki, Finland

Malmivaara-Lämsä M, Hamberg L, Haapamäki E, Liski J, Kotze DJ, Lehvävirta S, Fritze H (2008) Edge effects and trampling in boreal urban forest fragments - impacts on the soil microbial community. Soil Biol Biochem 40:1612-1621

Melliger RL, Rusterholz H-P, Baur B (2017) Ecosystem functioning in cities: combined effects of urbanisation and forest size on earlystage litter decomposition of European beech (Fagus sylvatica L.). Urban For Urban Gree 28:88-96

Meyer S, Rusterholz H-P, Salamon J-A, Baur B (2020) Leaf litter decomposition and litter fauna in urban forests: effect of the degree of urbanisation and forest size. Pedobiologia 78:150609

Milcu A, Manning P (2011) All size classes of soil fauna and litter quality control the acceleration of litter decay in its home environment. Oikos 120:1366-1370

Miles V, Esau I (2017) Seasonal and spatial characteristics of urban heat islands (UHIs) in northern Siberian cities. Remote Sens 9:989. https://doi.org/10.3390/rs9100989

Nassauer JI (1995) Messy ecosystems, orderly frames. Landsc J 14:161169

Ossola A, Aponte C, Hahs AK, Livesley SJ (2017) Contrasting effects of urban habitat complexity on metabolic functional diversity and composition of litter and soil bacterial communities. Urban Ecosyst 20: 595-607

Ossola A, Hahs AK, Nash MA, Livesley SJ (2016) Habitat complexity enhances comminution and decomposition processes in urban ecosystems. Ecosystems 19:927-941

Pouyat RV, Carreiro MM (2003) Controls on mass loss and nitrogen dynamics of oak leaf litter along an urban-rural land-use gradient. Oecologia 135:288-298

Pouyat RV, McDonnell MJ, Pickett STA (1997) Litter decomposition and nitrogen mineralization in oak stands along an urban-rural land use gradient. Urban Ecosyst 1:117-131
Pouyat RV, Parmelee RW, Carreiro MM (1994) Environmental effects on forest soil-invertebrate and fungal densities in oak stands along an urban-rural land use gradient. Pedobiologia 38:385-399

Pouyat RV, Setälä H, Szlavecz K, Yesilonis ID, Cilliers S, Hornung E, Yarwood S, Kotze DJ, Dombos M, McGuire MP, Whitlow TH (2017) Introducing GLUSEEN: a new open access and experimental network in urban soil ecology. Journal of Urban Ecology 3:1-10

Pouyat RV, Yesilonis ID, Dombos M, Szlavecz K, Setälä H, Cilliers S, Hornung E, Kotze DJ, Yarwood S (2015) A global comparison of surface soil characteristics across five cities: a test of the urban ecosystem convergence hypothesis. Soil Sci 180:136-145

R Core Team (2018) R: A language and environment for statistical computing. R Foundation for Statistical Computing, Vienna, Austria. URL https://www.R-project.org/

Riggs CE, Hobbie SE, Cavender-Bares J, Savage JA, Wei X (2015) Contrasting effects of plant species traits and moisture on the decomposition of multiple litter fractions. Oecologia 179:573-584

Savva Y, Szlavecz K, Pouyat RV, Groffman PM, Heisler G (2010) Effects of land use and vegetation cover on soil temperature in urban ecosystems. Soil Sci Soc Am J 74:469-480

Schimel JP, Schaeffer SM (2012) Microbial control over carbon cycling in soil. Front Microbiol 3(article 348):1-11

Schwarz N, Moretti M, Bugalho MN, Davies ZG, Haase D, Hack J, Hof A, Melero Y, Pett TJ, Knapp S (2017) Understanding biodiversityecosystem service relationships in urban areas: a comprehensive literature review. Ecosyst Serv 27:161-171

Setälä H, Marshall VG, Trofymov JA (1996) Influence of body size of soil fauna on litter decomposition and ${ }^{15} \mathrm{~N}$ uptake by poplar in a pot trial. Soil Biol Biochem 28:1661-1675

Setälä HM, Francini G, Allen JA, Hui N, Jumpponen A, Kotze DJ (2016) Vegetation type and age drive changes in soil properties, nitrogen, and carbon sequestration in urban parks under cold climate. Front Ecol Evol 4:93. https://doi.org/10.3389/fevo.2016.00093

Siitonen J (2001) Forest management, coarse woody debris and saproxylic organisms: Fennoscandian boreal forests as an example. Ecol Bull 49:11-41

Sterkenburg E, Bahr A, Brandström Durling M, Clemmensen KE, Lindahl BD (2015) Cahnges in fungal communities along a boreal forest fertility gradient. New Phytol 207:1145-1158

Tóth Z, Szlavecz K, Epp Schmidt DJ, Hornung E, Setälä H, Yesilonis ID, Kotze DJ, Dombos M, Pouyat R, Mishra S, Cilliers S, Yarwood S, Csuzdi C (2020) Earthworm assemblages in urban habitats across biogeographical regions. Appl Soil Ecol 151:103530

Veen GF, Freschet GT, Ordonez A, Wardle DA (2015) Litter quality and environmental controls of home-field advantage effects on litter decomposition. Oikos 124:187-195

Wall DH, Nielsen UN, Six J (2015) Soil biodiversity and human health. Nature 528:69-76

Wardle DA, Bardgett RD, Klironomos JN, Setälä H, Van Der Putten WH, Wall DH (2004) Ecological linkages between aboveground and belowground biota. Science 304:1629-1633

Weider RK, Lang GE (1982) A critique of the analytical methods used in examining decomposition data obtained from litter bags. Ecology 63:1636-1642

Zhang Y, Ji G, Wu T, Qiu J (2020) Urbanization significantly impacts the connectivity of soil microbes involved in nitrogen dynamics at a watershed scale. Environ Pollut 258:113708

Ziter C (2016) The biodiversity-ecosystem service relationship in urban areas: a quantitative review. Oikos 125:761-768 